\title{
Alkaloids from Acorus gramineus Rhizomes and their Biological Activity
}

\author{
Ki H. Kim, ${ }^{a}$ Eunjung Moon, ${ }^{b}$ Ki S. Kang, ${ }^{c}$ Sun Y. Kim, ${ }^{b}$ Sang U. Choi ${ }^{d}$ and Kang R. Lee ${ }^{*, a}$ \\ ${ }^{a}$ Natural Products Laboratory, School of Pharmacy, Sungkyunkwan University, \\ 440-746 Suwon, Republic of Korea \\ ${ }^{b}$ College of Pharmacy, Gachon University, 406-799 Incheon, Republic of Korea \\ ${ }^{c}$ College of Korean Medicine, Gachon University, 461-701 Seongnam, Republic of Korea \\ ${ }^{d}$ Korea Research Institute of Chemical Technology, 305-600 Deajeon, Republic of Korea
}

\begin{abstract}
Como parte de nossa pesquisa em andamento por constituintes bioativos de fontes medicinais coreanas, um fracionamento biomonitorado e uma investigação química de extrato metanólico de rizomas de Acorus gramineus resultaram no isolamento e identificação de dois alcaloides, incluindo um novo alcaloide do tipo aporfina, chamado gramichunosina e um alcaloide pirrol conhecido. Suas estruturas foram determinadas por uma combinação de análises espectroscópicas de ressonância magnética nuclear (NMR) 1D e 2D e espectrometria de massas de alta resolução (HRMS). Este é o primeiro relato de alcaloides de $A$. gramineus. Os compostos isolados apresentaram atividade antiproliferativa contra as linhagens de células A549, SK-OV-3, SK-MEL-2, e HCT-15 com EC 50 na faixa de 7,46-45,23 $\mu \mathrm{M}$. Ademais, as atividades antineuroinflamatórias desses compostos foram determinadas através da medida dos níveis de óxido nítrico (NO) meio utilizando células de microglia murina BV-2. O composto gramichunosina inibiu a produção de NO em células BV-2 estimuladas com lipopolisacarídeo com valores de $\mathrm{IC}_{50}$ de 7,83 $\mu \mathrm{M}$.
\end{abstract}

As part of our ongoing search for bioactive constituents from natural Korean medicinal resources, a bioassay-guided fractionation and a chemical investigation of the methanolic extract from the rhizomes of Acorus gramineus resulted in the isolation and identification of two alkaloids, including a new aporphine-type alkaloid, named gramichunosin, and a known pyrrole alkaloid. Their structures were determined by a combination of 1D and 2D nuclear magnetic resonance (NMR) spectroscopic analysis and high resolution mass spectrometry (HRMS). This is the first report of alkaloids from A. gramineus. The compounds isolated showed antiproliferative activities against A549, SK-OV-3, SK-MEL-2 and HCT-15 cell lines with $\mathrm{EC}_{50}$ values in the range of 7.46-45.23 $\mu \mathrm{M}$. Moreover, the anti-neuroinflammatory activities of these compounds were determined by measuring the nitric oxide (NO) levels in the medium using murine microglia BV-2 cells. Compound named gramichunosin inhibited NO production in lipopolysaccharide-stimulated BV-2 with $\mathrm{IC}_{50}$ values of $7.83 \mu \mathrm{M}$. activity

Keywords: Acorus gramineus, alkaloid, antiproliferative activity, anti-neuroinflammatory

\section{Introduction}

Alkaloids are a chemically heterogenous group of natural substance and compose more than 6000 basic nitrogen containing organic compounds that occur in about $15 \%$ of all vascular terresterial plants and in more than 150 different plant families. The alkaloids exhibit diverse structures as well as an extraordinary spectrum of pharmacological activities. ${ }^{1-3}$ Many researchers have been

*e-mail: krlee@skku.edu attracted by these characteristics of alkaloids for their chemical, biological and taxonomical studies.

Acorus gramineus Soland (Araceae) is an aquatic perennial herbaceous plant with semi-evergreen grasslike foliage. It is distributed in Korea, Japan and China, and its rhizomes have been used as a traditional medicine in China to treat various disorders including cognitive disorders, sedation, stomach ache and edema. ${ }^{4-6}$ Previous phytochemical studies of this plant reported some pharmacologically active phenolics, such as $\beta$-asarone, $\alpha$-asarone and phenylpropenes as well as lignans, 
which were associated with antibacterial, antifungal, anthelminthic, pesticidal and cytotoxic activities. ${ }^{7-12}$ As part of our ongoing search for bioactive constituents from natural Korean medicinal resources, we found that the methanolic $(\mathrm{MeOH})$ extract from the rhizomes of A. gramineus had excellent cytotoxic activity against A549, SK-OV-3 and SK-MEL-2 cells and showed inhibitory effects on nitric oxide (NO) production using an activated murine microglial cell line in our preliminary studies.

Our continuing interest in the research on bioactive constituents from this plant led us to investigate bioactive metabolites of A. gramineus rhizomes. A bioassay-guided fractionation and chemical investigation of its $\mathrm{MeOH}$ extract resulted in the isolation and identification of two alkaloids, including a new aporphine-type alkaloid (1), named gramichunosin, and a known pyrrole alkaloid (2). This report will discuss the isolation and structural elucidation of the two alkaloids from A. gramineus rhizomes (Figure 1), as well as their antiproliferative activities against A549, SK-OV-3, SK-MEL-2 and HCT-15 cell lines and their inhibitory effects on NO production in a lipopolysaccharide (LPS)-activated BV2 cell line.
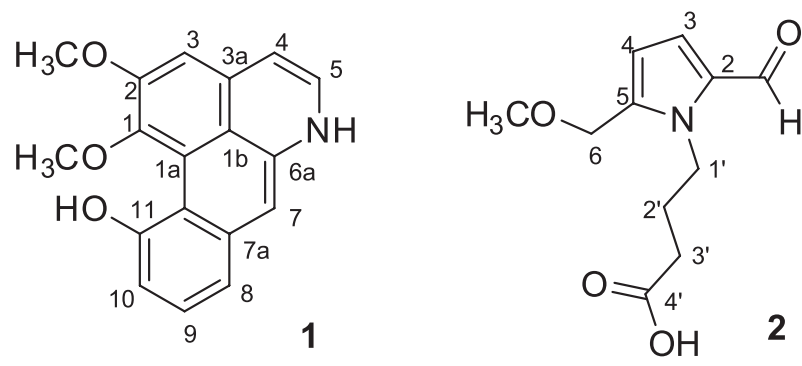

Figure 1. Structures of compounds $\mathbf{1}$ and $\mathbf{2}$ isolated from A. gramineus.

\section{Experimental}

\section{General experimental procedures}

Melting point was determined on a Gallenkamp melting point apparatus and is uncorrected. Infrared (IR) spectra were recorded on a Bruker IFS-66/S FT-IR spectrometer (Bruker, Karlsruhe, Germany). UV spectra were recorded with a Shimadzu UV-1601 UV-Vis spectrophotometer (Shimadzu, Tokyo, Japan). Electrospray ionization mass spectrometry (ESIMS) and high resolution electrospray ionization mass spectrometry (ESI-MS) (HR-ESIMS) spectra were recorded on a Micromass QTOF2-MS (MicroMass, Waters, Milford, MA, USA). Nuclear magnetic resonance (NMR) spectra, including ${ }^{1} \mathrm{H}-{ }^{-1} \mathrm{H}$ COSY, HMQC, and HMBC experiments, were recorded on a Varian UNITY INOVA 500 NMR spectrometer (Varian, Palo Alto, CA, USA) operating at $500 \mathrm{MHz}\left({ }^{1} \mathrm{H}\right)$ and $125 \mathrm{MHz}\left({ }^{13} \mathrm{C}\right)$, with chemical shifts given in $\operatorname{ppm}(\delta)$. Semi-preparative high performance liquid chromatography (HPLC) was conducted using a Gilson 306 pump (Gilson, Middleton, WI) with Shodex refractive index detector (Shodex, New York, NY). Silica gel 60 and RP-C 18 silica gel (230-400 mesh, Merck, Darmstadt, Germany) were used for column chromatography. The packing material for molecular sieve column chromatography was Sephadex LH-20 (Pharmacia, Uppsala, Sweden). Merck precoated silica gel $\mathrm{F}_{254}$ plates and RP-18 $\mathrm{F}_{254 \mathrm{~s}}$ plates (Merck, Darmstadt, Germany) were used for thin layer chromatography (TLC). Spots were detected on TLC under UV light or by heating after spraying with $10 \% \mathrm{H}_{2} \mathrm{SO}_{4}$ in $\mathrm{C}_{2} \mathrm{H}_{5} \mathrm{OH}(\mathrm{v} / \mathrm{v})$.

\section{Plant material}

The rhizomes of A. gramineus were collected from Jeju Island, Korea, in March 2009, and the plant was identified by one of the authors (K. R. L.). A voucher specimen (SKKU-NPL-0910) has been deposited in the herbarium of the School of Pharmacy, Sungkyunkwan University, Suwon, Korea.

\section{Extraction and isolation}

The rhizomes of $A$. gramineus ( $15 \mathrm{~kg}$ ) were extracted with $80 \%$ aqueous $\mathrm{MeOH}$ at room temperature and filtered. The filtrate was evaporated under vacuum to obtain a $\mathrm{MeOH}$ extract $(825 \mathrm{~g})$, which was suspended in distilled $\mathrm{H}_{2} \mathrm{O}$ $(2 \mathrm{~L})$ and successively solvent-partitioned with $n$-hexane, $\mathrm{CHCl}_{3}$, EtOAc and $n$-BuOH, yielding 166, 14, 5 and $47 \mathrm{~g}$ of residues, respectively. Each fraction was evaluated for cytotoxicity against A549, SK-OV-3 and SK-MEL-2 cells using a sulforhodamine B (SRB) assay. The $n$-hexanesoluble and EtOAc-soluble fractions showed significant cytotoxic activity against tested cancer cell lines. The active fractions also inhibited NO production in LPS-stimulated BV-2 cells. The $n$-hexane-soluble fraction $(62 \mathrm{~g})$ was separated over a silica gel column chromatography with $n$-hexane-EtOAc (11:1) to yield eight fractions (H1-H8). Fraction H8 (2 g) was applied to $\mathrm{RP}_{-} \mathrm{C}_{18}$ silica gel column chromatography using a solvent system of $\mathrm{MeOH}-\mathrm{H}_{2} \mathrm{O}$ (1:1) to give six subfractions (H8a-H8f). Fraction H8d (156 mg) was subjected to a Sephadex LH-20 column using a solvent system of $\mathrm{CH}_{2} \mathrm{Cl}_{2}-\mathrm{MeOH}$ (1:1), and further purified by semi-preparative reversed-phase HPLC using a $250 \mathrm{~mm} \times 10 \mathrm{~mm}$ i.d., $10 \mu \mathrm{m}$, Econosil RP-18 column (Alltech, Nicholasville, KY, USA) with a solvent system of $100 \% \mathrm{MeOH}$ (flow rate; $2 \mathrm{~mL} \mathrm{~min}^{-1}$ ) to obtain compound $1\left(7 \mathrm{mg}, t_{\mathrm{R}}=23.5 \mathrm{~min}\right)$. Another active fraction, EtOAc-soluble fraction ( $5 \mathrm{~g}$ ) was separated over a RP-C 18 
silica gel column chromatography using a solvent system of $\mathrm{MeOH}-\mathrm{H}_{2} \mathrm{O}$ (1:1) to provide eight fractions (E1-E8). Fraction E3 (870 mg) was applied to a silica gel column chromatography with $\mathrm{CHCl}_{3}-\mathrm{MeOH}(25: 1)$ to obtain five subfractions (E3a-E3e). Fraction E3d (83 mg) was subjected to a Sephadex LH-20 column using a solvent system of MeOH- $\mathrm{H}_{2} \mathrm{O}$ (4:1), and further purified by semipreparative reversed-phase HPLC with a solvent system of $\mathrm{MeOH}-\mathrm{H}_{2} \mathrm{O}\left(2: 3\right.$, flow rate of $\left.2 \mathrm{~mL} \mathrm{~min}{ }^{-1}\right)$ to furnish compound 2 (13 mg, $\left.t_{\mathrm{R}}=18.0 \mathrm{~min}\right)$.

\section{Gramichunosin (1)}

Yellowish powder; m.p. $308-309{ }^{\circ} \mathrm{C}$; UV $(\mathrm{MeOH})$ $\lambda_{\max } / \mathrm{nm}(\log \varepsilon) 392$ (1.8), 272 (3.5), 232 (3.1); IR (KBr) $v_{\max } / \mathrm{cm}^{-1} 3357,2945,2832,1451,1116,1032,674$; ${ }^{1} \mathrm{H}(500 \mathrm{MHz})$ and ${ }^{13} \mathrm{C}(125 \mathrm{MHz}) \mathrm{NMR}$ data, see Table 1; ESIMS (positive-ion mode) $\mathrm{m} / \mathrm{z} 294[\mathrm{M}+\mathrm{H}]^{+}$; HR-ESIMS (positive-ion mode) $\mathrm{m} / z 316.0951[\mathrm{M}+\mathrm{Na}]^{+}$(calcd. for $\left.\mathrm{C}_{18} \mathrm{H}_{15} \mathrm{NO}_{3} \mathrm{Na}, 316.0950\right)$.

4-(2-Formyl-5-(methoxymethyl)-1 H-pyrrol-1-yl)butanoic acid (2)

Brown gum; UV (MeOH) $\lambda_{\max } / \mathrm{nm}(\log \varepsilon) 290$ (3.8); IR (KBr) $v_{\text {max }} / \mathrm{cm}^{-1} 3435,2929,1733,1660,1450,1352$, 1031, 670; ${ }^{1} \mathrm{H}(500 \mathrm{MHz})$ and ${ }^{13} \mathrm{C}(125 \mathrm{MHz})$ NMR data, see Table 2; ESIMS (positive-ion mode) $\mathrm{m} / z 226[\mathrm{M}+\mathrm{H}]^{+}$.

\section{Cell cultures}

All tumor cell cultures were maintained using RPMI1640 cell growth medium (Gibco, Carlsbad, CA), supplemented with $5 \%$ fetal bovine serum (FBS) (Gibco), 100 units $\mathrm{mL}^{-1}$ penicillin and $100 \mu \mathrm{g} \mathrm{mL}^{-1}$ streptomycin. Human tumor cell lines such as A549 (non-small cell lung carcinoma), SK-OV-3 (ovary malignant ascites), SK-MEL-2 (skin melanoma) and HCT-15 (colon adenocarcinoma) were provided by the National Cancer Institute (NCI). Murine microglial BV2 was generously provided by Dr E. Choi from Korea University (Seoul, Korea). It was maintained in Dulbecco's modified Eagle (DMEM) medium supplemented with 5\% FBS, 100 units $\mathrm{mL}^{-1}$ penicillin and $100 \mu \mathrm{g} \mathrm{mL} \mathrm{m}^{-1}$ streptomycin. All cells were incubated at $37^{\circ} \mathrm{C}$ in a humidified incubator with $5 \% \mathrm{CO}_{2}$.

\section{Cytotoxicity assessment}

The cytotoxicity of the compounds against cultured human tumor cell lines was evaluated by the sulforhodamine B (SRB) method. ${ }^{13}$ Each tumor cell line was inoculated over standard 96-well flat-bottom microplates and then incubated for $24 \mathrm{~h}$ at $37{ }^{\circ} \mathrm{C}$ in a humidified atmosphere of $5 \% \mathrm{CO}_{2}$. The attached cells were then incubated with the serially diluted samples. Control cultures received the carrier solvent ( $0.1 \%$ dimethyl sulfoxide). After continuous exposure to the compounds for $48 \mathrm{~h}$, the culture medium was removed from each well and the cells were fixed with $10 \%$ cold trichloroacetic acid at $4{ }^{\circ} \mathrm{C}$ for $1 \mathrm{~h}$. After washing with tap water, the cells were stained with $0.4 \%$ SRB dye and incubated for $30 \mathrm{~min}$ at room temperature. The cells were washed again and then solubilized with $10 \mathrm{mM}$ unbuffered Tris base solution ( $\mathrm{pH}$ 10.5). The absorbance was measured spectrophotometrically at $520 \mathrm{~nm}$ with a microtiter plate reader. Doxorubicin (purity $\geq 98 \%$, Sigma) was used as a positive control. Tested compounds were demonstrated to be pure as evidenced by NMR and HPLC analysis (purity $\geq 95 \%$ ).

\section{Measurement of NO production}

BV-2 cells were plated into a 96-well plate $\left(3 \times 10^{4}\right.$ cells well $\left.{ }^{-1}\right)$. After $24 \mathrm{~h}$, cells were pretreated with the compounds for $30 \mathrm{~min}$, and stimulated with $100 \mathrm{ng} \mathrm{mL}^{-1}$ of LPS for another $24 \mathrm{~h}$. Control cultures received the carrier solvent ( $0.1 \%$ dimethyl sulfoxide). Nitrite, a soluble oxidation product of NO, was measured in the culture media using the Griess reaction. The supernatant $(50 \mu \mathrm{L})$ was harvested and mixed with an equal volume of Griess reagent ( $1 \%$ sulfanilamide, $0.1 \%$ $N$-1-napthylethylenediamine dihydrochloride in 5\% phosphoric acid). After $10 \mathrm{~min}$, the absorbance at $570 \mathrm{~nm}$ was measured using a microplate reader. Sodium nitrite was used as a standard to calculate the $\mathrm{NO}_{2}^{-}$concentration. $N^{\mathrm{G}}$-monomethyl-L-arginine (NMMA, Sigma, St. Louis, MO, USA), a well-known NO synthase inhibitor, was tested as a positive control. ${ }^{14}$

\section{Results and Discussion}

The $\mathrm{MeOH}$ extract of $A$. gramineus rhizomes was subjected to liquid-liquid solvent-partitioning to yield $n$-hexane, $\mathrm{CHCl}_{3}, \mathrm{EtOAc}$ and $n$ - $\mathrm{BuOH}$ soluble factions. Among them, the active $n$-hexane-soluble and EtOAc-soluble fractions were further separated by silica gel or Sephadex LH-20 column chromatography, and subsequent HPLC to give two alkaloids ( $\mathbf{1}$ and $\mathbf{2}$ ). To the best of our knowledge, the presence of alkaloids is reported from A. gramineus for the first time in this study.

Compound 1, obtained as yellowish powder, gave a positive test with Dragendorff's reagent. The molecular formula was determined to be $\mathrm{C}_{18} \mathrm{H}_{15} \mathrm{NO}_{3}$ from the $[\mathrm{M}+\mathrm{Na}]^{+}$peak at $\mathrm{m} / \mathrm{z}, 316.0951$ (calcd. for $\mathrm{C}_{18} \mathrm{H}_{15} \mathrm{NO}_{3} \mathrm{Na}$, 316.0950) in the HR-ESIMS data. The IR spectrum 
indicated that 1 possessed hydroxyl $\left(3357 \mathrm{~cm}^{-1}\right)$ and aromatic $\left(1451 \mathrm{~cm}^{-1}\right)$ groups. The UV spectrum exhibited absorption bands at $\lambda_{\max } 232,272$ and $392 \mathrm{~nm}$, suggesting the presence of the conjugated double-bond system. The ${ }^{1} \mathrm{H}$ NMR spectral data (Table 1) showed the presence of seven protons consisting of two vicinal coupled aromatic protons at $\delta_{\mathrm{H}} 8.58(\mathrm{~d}, J 6.0 \mathrm{~Hz})$ and $7.41(\mathrm{~d}, J 6.0 \mathrm{~Hz})$, three vicinal coupled aromatic protons at $\delta_{\mathrm{H}} 7.65(\mathrm{~d}, J 7.5 \mathrm{~Hz})$, $7.35(\mathrm{t}, J 7.5 \mathrm{~Hz})$ and $6.98(\mathrm{~d}, J 7.5 \mathrm{~Hz})$ and two singlets of uncoupled aromatic protons at $\delta_{\mathrm{H}} 8.78(\mathrm{~s})$ and $7.00(\mathrm{~s})$. In addition, two sharp singlets at $\delta_{\mathrm{H}} 4.18(3 \mathrm{H}, \mathrm{s})$ and $4.06(3 \mathrm{H}$, $\mathrm{s})$, representing aromatic methoxy groups, were observed in the ${ }^{1} \mathrm{H}$ NMR spectrum. The ${ }^{13} \mathrm{C}$ NMR spectrum (Table 1 ) of 1 showed 18 carbon signals including two methoxy signals $\left(\delta_{\mathrm{C}} 63.3\right.$ and 56.6) and five oxygenated or nitrogenated carbon signals $\left(\delta_{\mathrm{C}} 159.3,158.0,153.1,146.3\right.$ and 143.7), all of which were classified as olefinic or aromatic carbon signals except for two methoxy signals. Overall, the proton and carbon signals in the ${ }^{1} \mathrm{H}$ and ${ }^{13} \mathrm{C}$ NMR data of $\mathbf{1}$ implied that compound $\mathbf{1}$ may be a trioxygenated aporphine-type alkaloid by the aforementioned evidence and reported literatures..$^{15-18}$

The structure of the aporphine-type skeleton was ultimately elucidated by the interpretation of the ${ }^{1} \mathrm{H}-{ }^{1} \mathrm{H}$ correlated spectroscopy (COSY), heteronuclear multiple quantum correlation (HMQC), and heteronuclear multiple bond correlation (HMBC) data. The HMQC spectrum permitted the correlation of all protonated carbons. The HMBC data was crucial to confirming the structural assignments and correctly positing the methoxy and hydroxy groups and all non-protonated carbons. The COSY spectrum showed two different spin systems of H-4/H-5 and H-8/H-9/H-10 by their COSY correlations (Figure 2). The down-field shifted proton at $\mathrm{H}-5\left(\delta_{\mathrm{H}} 8.58\right)$ suggested that the proton is adjacent to nitrogen atom, while the HMBC cross-peaks of H-5/C-3a and H-5/C6a as well as H-3/C-1, H-3/C-2, H-3/C-1b, H-4/C-3 and $\mathrm{H}-4 / \mathrm{C}-1 \mathrm{~b}$ allowed us to establish the partial structure from C-1 to C-6a (Figure 2). Particularly, the positions of two methoxy groups were confirmed to be at $\mathrm{C}-1$ and $\mathrm{C}-2$ by the $\mathrm{HMBC}$ correlations between $1-\mathrm{OCH}_{3}\left(\delta_{\mathrm{H}} 4.18\right)$ and $\mathrm{C}-1\left(\delta_{\mathrm{C}} 143.7\right)$ and between $2-\mathrm{OCH}_{3}\left(\delta_{\mathrm{H}} 4.06\right)$ and $\mathrm{C}-2\left(\delta_{\mathrm{C}} 158.0\right)$, respectively. In addition, the other remaining structure was elucidated by the $\mathrm{H}-8 / \mathrm{H}-9 / \mathrm{H}-10$ COSY system and the HMBC correlations of $\mathrm{H}-7 / \mathrm{C}-1 \mathrm{~b}$, H-7C-8, H-7/C-11a, H-8/C-11a, H-9/C-7a, H-9/C-11, H-10/C-8 and H-10/H-11a (Figure 2). Finally, even though $\mathrm{HMBC}$ correlation between $\mathrm{C}-1 \mathrm{a}$ and any protons was not observed, the connectivity of C-1-C-1a-C-11a was clearly deduced based on the molecular formula after connecting other partial structures. Thus, the gross structure of 1 was established as shown in Figure 1 and named gramichunosin. To our knowledge, an aporphine alkaloid with similar structural feature was isolated from the stem bark of Enantia chlorantha, and identified as 6a,7-dehydro-1,2-dimethoxy-7-hydroxyaporphine. ${ }^{19}$ It shares 6a,7-dehydro-1,2-dimethoxy-aporphine skeleton, whereas it has hydroxyl group at C-7 and saturation at C-4/C-5.

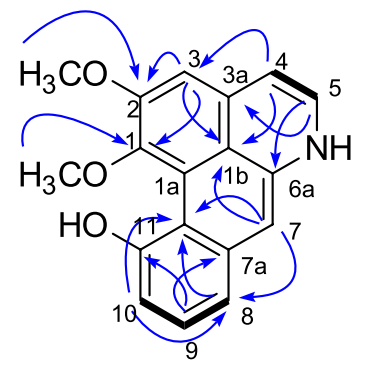

Figure 2. The ${ }^{1} \mathrm{H}-{ }^{1} \mathrm{H}$ COSY correlations (bond) and key $\mathrm{HMBC}$ correlations $(\mathrm{H} \rightarrow \mathrm{C})$ of $\mathbf{1}$.

Table 1. ${ }^{1} \mathrm{H}$ and ${ }^{13} \mathrm{C}$ NMR data of compounds $\mathbf{1}$ and $\mathbf{2}$ in $\mathrm{CDCl}_{3}{ }^{\mathrm{a}}$

\begin{tabular}{|c|c|c|c|c|c|}
\hline \multirow{2}{*}{ Position } & \multicolumn{2}{|c|}{1} & \multirow{2}{*}{ Position } & \multicolumn{2}{|c|}{2} \\
\hline & $\delta_{\mathrm{H}}$ & $\delta_{\mathrm{C}}$ & & $\delta_{\mathrm{H}}$ & $\delta_{\mathrm{C}}$ \\
\hline 1 & - & 143.7 & 2 & - & 132.5 \\
\hline $1 \mathrm{a}$ & - & 122.9 & 3 & $6.90 \mathrm{~d}(4.0)$ & 124.4 \\
\hline $1 b$ & - & 126.0 & 4 & $6.25 \mathrm{~d}(4.0)$ & 111.7 \\
\hline 2 & - & 158.0 & 5 & - & 138.8 \\
\hline 3 & $7.00 \mathrm{~s}$ & 104.9 & 6 & $4.46 \mathrm{~s}$ & 65.4 \\
\hline $3 a$ & - & 131.4 & $\mathrm{CHO}$ & $9.50 \mathrm{~s}$ & 179.5 \\
\hline 4 & $7.41 \mathrm{~d}(6.0)$ & 117.2 & $\mathrm{OCH}_{3}$ & $3.36 \mathrm{~s}$ & 57.9 \\
\hline 5 & $8.58 \mathrm{~d}(6.0)$ & 146.3 & $1^{\prime}$ & $4.40 \mathrm{t}(7.5)$ & 44.7 \\
\hline $6 a$ & - & 159.3 & $2^{\prime}$ & 2.07 t (7.5) & 26.0 \\
\hline 7 & $8.78 \mathrm{~s}$ & 126.0 & $3^{\prime}$ & $2.43 \mathrm{t}(7.5)$ & 30.7 \\
\hline $7 \mathrm{a}$ & - & 140.8 & $4^{\prime}$ & - & 178.3 \\
\hline 8 & $6.98 \mathrm{~d}(7.5)$ & 118.6 & - & - & - \\
\hline 9 & 7.35 t (7.5) & 131.4 & - & - & - \\
\hline 10 & $7.65 \mathrm{~d}(7.5)$ & 114.5 & - & - & - \\
\hline 11 & - & 153.1 & - & - & - \\
\hline $11 \mathrm{a}$ & - & 122.6 & - & - & - \\
\hline $1-\mathrm{OCH}_{3}$ & $4.18 \mathrm{~s}$ & 63.3 & - & - & - \\
\hline $2-\mathrm{OCH}_{3}$ & $4.06 \mathrm{~s}$ & 56.6 & - & - & - \\
\hline
\end{tabular}

${ }^{a}{ }^{1} \mathrm{H}$ and ${ }^{13} \mathrm{C}$ NMR data were recorded at 500 and $125 \mathrm{MHz}$, respectively. Coupling constants (in $\mathrm{Hz}$ ) are given in parentheses.

Compound 2 was obtained as a brown gum. The molecular formula was determined as $\mathrm{C}_{11} \mathrm{H}_{15} \mathrm{NO}_{4}$ from the molecular ion peak $[\mathrm{M}+\mathrm{H}]^{+}$at $m / z 226[\mathrm{M}+\mathrm{H}]^{+}$in the ESIMS. The IR spectrum exhibited absorptions of 
carboxylic acid $\left(1733 \mathrm{~cm}^{-1}\right)$ and aldehyde $\left(1660 \mathrm{~cm}^{-1}\right)$ groups. Compound $\mathbf{2}$ had a UV spectrum characteristic of pyrrole-2-aldehyde with an absorption maximum at $290 \mathrm{~nm} .{ }^{20}$ Inspection of the ${ }^{1} \mathrm{H}$ chemical shifts and coupling constants of signals at $\delta_{\mathrm{H}} 6.90(\mathrm{~d}, J 4.0 \mathrm{~Hz})$ and $6.25(\mathrm{~d}, J 4.0 \mathrm{~Hz})$ implied the presence of a heterocyclic ring containing a nitrogen atom and the coupling constant of $4.0 \mathrm{~Hz}$ indicated 2,5-disubstituted pyrrole ring. ${ }^{21}$ The characteristic signal at $\delta_{\mathrm{H}} 9.50$ in the ${ }^{1} \mathrm{H}$ NMR spectrum and at $\delta_{\mathrm{C}} 179.5$ in the ${ }^{13} \mathrm{C}$ NMR spectrum (Table 1) were indicative of an aldehyde, and a singlet signal at $\delta_{\mathrm{H}} 4.46$ $\left(\delta_{\mathrm{C}} 65.4\right)$ was assigned to an oxygenated methylene group. The partial structure of 2,5-disubstituted pyrrole ring was established by the analysis of the ${ }^{1} \mathrm{H}-{ }^{1} \mathrm{H}$ COSY and HMBC spectroscopic data (Figure 3), and the location of a methoxy group was confirmed to be $\mathrm{C}-6$ by the HMBC correlation between the methoxy proton $\left(\delta_{\mathrm{H}} 3.36\right)$ and C-6 $\left(\delta_{\mathrm{C}} 65.4\right)$. A butanoic acid unit was also assigned as a side chain by the COSY correlations from H-1' to H-3' and HMBC cross peaks of $\mathrm{H}-2^{\prime} / \mathrm{C}-4$ and H-3'/C-4 (Figure 3). Finally, the connectivity of the side chain to the pyrrole ring was suggested by the observation of HMBC correlations from H-1' to C-2 and C-5. According to these pieces of evidence, the structure of 2 was elucidated to be 4-(2-formyl-5(methoxymethyl)-1H-pyrrol-1-yl)butanoic acid. As a result of the literature survey, compound $\mathbf{2}$ was already reported from Lycium chinense fruits. ${ }^{21}$ However, the reported ${ }^{13} \mathrm{C}$ NMR data did not match completely with our ${ }^{13} \mathrm{C}$ NMR assignments, even though the NMR data were obtained in the same solvent $\left(\mathrm{CDCl}_{3}\right)$. In particular, most of ${ }^{13} \mathrm{C} \mathrm{NMR}$

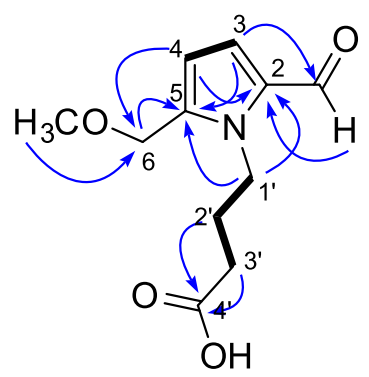

Figure 3. The ${ }^{1} \mathrm{H}-{ }^{1} \mathrm{H}$ COSY correlations (bond) and key HMBC correlations $(\mathrm{H} \rightarrow \mathrm{C})$ of $\mathbf{2}$. data of $\mathbf{2}$ were not much different from the reported data in the difference-range of 0.1-0.4 ppm, whereas the ${ }^{13} \mathrm{C}$ chemical shift of C-5 $\left(\delta_{\mathrm{C}} 138.8\right)$ was obviously different $\left(\Delta \delta_{\mathrm{C}-5}-5.1 \mathrm{ppm}\right)$ and that of C-4' was also slightly different $\left(\Delta \delta_{\mathrm{C}-4^{+}}+2.3 \mathrm{ppm}\right)$. Thus, we suggest that the assignments of ${ }^{13} \mathrm{C}$ NMR for $\mathbf{2}$ should be corrected as the data we are publishing in this study.

The antiproliferative activities of the alkaloids 1-2 were evaluated by determining their inhibitory effects on four human tumor cell lines, namely A549 (nonsmall cell lung carcinoma), SK-OV-3 (ovary malignant ascites), SK-MEL-2 (skin melanoma) and HCT-15 (colon adenocarcinoma) using the SRB bioassay. ${ }^{13}$ The results (Table 2) showed that compounds $\mathbf{1}$ and $\mathbf{2}$ showed moderate antiproliferative activities against SK-OV-3 and SK-MEL-2 cell lines with $\mathrm{EC}_{50}$ values ranging from 7.46 to $23.59 \mu \mathrm{M}$. Moreover, they showed weak inhibitory activity against the proliferation of the A549 and HCT-15 cell lines with $\mathrm{EC}_{50}$ values in the range of 37.23-45.23 $\mu \mathrm{M}$ (Table 2).

Next, the anti-neuroinflammatory activities of the compounds 1 and $\mathbf{2}$ were evaluated by measuring the produced NO levels in LPS-activated microglia BV-2 cells. Microglia cells, the unique population of the central nervous system resident immune cells, have been implicated in the pathogenesis of a variety of neurodegenerative diseases including Parkinson's disease and Alzheimer's disease. ${ }^{22,23}$ Excessive production of NO and proinflammatory cytokines from activated microglia play an important role in neurodegenerative disorders. Therefore, regulation of the microglial activation will be an important strategy to prevent the progressive damage of the neurodegenerative diseases. In this test, compound 1 significantly inhibited LPS-stimulated NO production with $\mathrm{IC}_{50}$ values of $7.83 \mu \mathrm{M}$, which displayed more activity than a positive control, $N^{\mathrm{G}}$-nonomethyl-L-arginine (L-NMMA; a well-known NOS inhibitor, $\mathrm{IC}_{50}$ value of $14.27 \mu \mathrm{M})$. However, compound 2 had no influence on NO levels in the medium $\left(\mathrm{IC}_{50}>200 \mu \mathrm{M}\right)$. The isolates 1-2 had no influence on cell viability (data not shown) at concentrations up to $20 \mu \mathrm{M}$.

Table 2. Antiproliferative activities of compounds $\mathbf{1}$ and $\mathbf{2}$ isolated from A. gramineus

\begin{tabular}{lcccc}
\hline \multirow{2}{*}{ Compound } & \multicolumn{3}{c}{$\mathrm{EC}_{50} / \mu \mathrm{M}^{\mathrm{a}}$} \\
\cline { 2 - 5 } $\mathbf{1}$ & $\mathrm{A} 549$ & $\mathrm{SK}-\mathrm{SV}-3$ & $\mathrm{SK}-\mathrm{MEL}-2$ & $\mathrm{HCT}-15$ \\
$\mathbf{2}$ & $39.06 \pm 1.85^{\mathrm{b}}$ & $7.46 \pm 0.78$ & $19.77 \pm 1.52$ & $45.23 \pm 3.02$ \\
Doxorubicin $^{\mathrm{c}}$ & $40.74 \pm 2.41$ & $21.52 \pm 1.82$ & $23.59 \pm 2.47$ & $37.23 \pm 0.97$ \\
\hline
\end{tabular}

${ }^{\mathrm{a}} \mathrm{EC}_{50}$ value of compounds against each cancer cell line. $\mathrm{EC}_{50}$ value was defined as concentration $(\mu \mathrm{M})$ causing $50 \%$ inhibition of cell growth in vitro; ${ }^{\text {b data }}$ are expressed as mean \pm SEM of three independent experiments; ' doxorubicin as a positive control. 


\section{Conclusions}

The bioassay-guided fractionation and chemical investigation of A. gramineus rhizomes resulted in the isolation and identification of two alkaloids, including a new aporphine-type alkaloid, gramichunosin (1). The corrected assignments in ${ }^{13} \mathrm{C}$ NMR of compound 2 were also suggested in this study. To our knowledge, this is the first report to investigate alkaloidal compounds from A. gramineus. The isolated alkaloids displayed antiproliferative activities by suppressing the survival of human cancer cells (A549, SK-OV-3, SK-MEL-2 and HCT-15). Particularly, compound 1 exhibited significant anti-neuroinflammatory activity by inhibiting the NO production in LPS-stimulated microglial BV-2. These results suggest that compound $\mathbf{1}$ can be applied as the key compound in the drug development for various cancers and neuroinflammatory diseases. In addition, its anti-neuroinflammatory activity supports the folk usage of A. gramineus in the treatment of cognitive disorders, and it is possible that compound $\mathbf{1}$ may be one of the active ingredients responsible for the cognitive improvement.

\section{Supplementary Information}

Supplementary data are available free of charge at http://jbcs.sbq.org.br as a PDF file.

\section{Acknowledgments}

This work was supported by the KIST Institutional Program (Project No. 2Z04210-14-124). We are thankful to the Korea Basic Science Institute (KBSI) for the measurements of NMR and MS spectra.

\section{References}

1. Fattorusso, E.; Taglialatela-Scafati, O.; Modern Alkaloids: Structure, Isolation, Synthesis, and Biology; Wiley-VCH: Weinheim, 2008.

2. Souto, A. L.; Tavares, J. F.; Silva, M. S.; Diniz, M. F. F. M.; Athayde-Filho, P. F.; Barbosa-Filho, J. M.; Molecules 2011, 16, 8515.
3. Lu, J. J.; Bao, J. L.; Chen, X. P.; Huang, M.; Wang, Y. T.; Evid. Based Complement. Alternat. Med. 2012, 2012, 485042.

4. Liao, J. F.; Huang, S. Y.; Jan, Y. M.; Yu, L. L.; Chen, C. F.; J. Ethnopharmacol. 1998, 61, 185.

5. Tang, W.; Eisenbrand, G.; Chinese Drugs of Plant Origin; Springer: New York, 1992.

6. Wang, H. Z.; Cheng, Y. G.; Fan, C. S.; Acta Bot. Yunnanica 1998, $5,96$.

7. Greca, M. D.; Monaco, P.; Previtera, L.; Aliotta, G.; Pinto, G.; Pollio, A.; Phytochemistry 1989, 28, 2319.

8. Lee, J. Y.; Lee, J. Y.; Yun, B. S.; Hwang, B. K.; J. Agric. Food Chem. 2004, 52, 776.

9. Perrett, S.; Whitfield, P. J.; Phytother. Res. 1995, 9, 405.

10. McGaw, L. J.; Jager, A. K.; van Staden, J.; S. Afr. J. Bot. 2002, 68,31 .

11. Kim, K. H.; Kim, H. K.; Choi, S. U.; Moon, E.; Kim, S. Y.; Lee, K. R.; J. Nat. Prod. 2011, 74, 2187.

12. Kim, K. H.; Moon, E.; Kim, H. K.; Oh, J. Y.; Kim, S. Y.; Choi, S. U.; Lee, K. R.; Bioorg. Med. Chem. Lett. 2012, 22, 6155.

13. Skehan, P.; Storeng, R.; Scudiero, D.; Monks, A.; MaMahon, J.; Vistica, D.; Warren, J. T.; Bokesch, H.; Kenney, S.; Boyd, M. R.; J. Natl. Cancer Inst. 1990, 82, 1107.

14. Reif, D. W.; McCreedy, S. A.; Arch. Biochem. Biophys. 1995, 1,170 .

15. Priestap, H. A.; Magn. Reson. Chem. 1989, 27, 460.

16. Priestap, H. A.; Phytochemistry 1985, 24, 849.

17. Kim, S. K.; Ryu, S. Y.; No, J.; Choi, S. U.; Kim, Y. S.; Arch. Pharm. Sci. Res. 2001, 24, 518.

18. Kim, K. H.; Piao, C. J.; Choi, S. U.; Son, M. W.; Lee, K. R.; Planta Med. 2010, 76, 1732.

19. Wafo, P.; Nyasse, B.; Fontaine, C.; Sondengam, B. L.; Fitoterapia 1999, 70, 157.

20. Shigagetsu, H.; Shibata, S.; Kurata, T.; Kato, H.; Fujimaki, M.; Agric. Biol. Chem. 1977, 41, 2377.

21. Chin, Y. W.; Lim, S. W.; Kim, S. H.; Shin, D. Y.; Suh, Y. G.; Kim, Y. B.; Kim, Y. C.; Kim, J.; Bioorg. Med. Chem. Lett. 2003, 13,79 .

22. Wilms, H.; Zecca, L.; Rosenstiel, P.; Sievers, J.; Deuschl, G.; Lucius, R.; Curr. Pharm. Des. 2007, 13, 1925.

23. McGeer, P. L.; McGeer, E. G.; Brain Res. Rev. 1995, 21, 195.

Submitted: July 31, 2014

Published online: September 5, 2014 